\title{
Environment for the Formation of Shale Oil and Gas Accumulations in Low-Permeability Sequences of the Maikop Series, Fore-Caucasus.
}

\author{
V.YU. KERIMOV ${ }^{1}$, R.N. MUSTAEV ${ }^{1}$, N.SH. YANDARBIEV ${ }^{2}$ and E.M. MOVSUMZADE ${ }^{3}$ \\ ${ }^{1}$ Gubkin Russian State University of Oil and Gas (National Research University) \\ 65 LeninskyProspekt, Moscow, 119991, Russian Federation \\ ${ }^{2}$ Lomonosov Moscow State UniversityLeninskie Gory, Moscow, 119991, Russian Federation \\ ${ }^{3}$ Ufa State Petroleum Technological University 1 Kosmonavtov St., Ufa 450062, Russian Federation \\ ${ }^{*}$ Corresponding author E-mail: r.mustaev@ mail.ru \\ http://dx.doi.org/10.13005/ojc/330237
}

(Received: February 17, 2017; Accepted: March 15, 2017)

The studies were carried out with the financial support of the Ministry of Education and Science of Russia within the framework of the Task No. 10.6569.2017 / BP for the implementation of research work (the basic part of the state task in the area of scientific activity)

\begin{abstract}
The article is devoted to a study of the generative potential of the Maikop series in the Fore-Caucasus. The series is among the promising for the discovery of «shale» hydrocarbons in the Russian territory. For its evaluation have been conducted laboratory studies including chemicobituminological, pyrolitic and coal petrography analyses of the organic matter. The article analyzes the issues of zoning the Khadum and Batalpashin Formations in the Central and Eastern Fore-Caucasus by geochemical criteria. Conclusions are made that a significant part of the Khadum and Batalpashin sediments in the study region is both at the approach to and within the "oil window». For the first time for this region was conducted a quantitative evaluation of the generative hydrocarbon potential of the Khadum and Batalpashin sediments.
\end{abstract}

Keywords: Khadum Formation, Fore-Caucasus, geochemical studies, shale hydrocarbons, generative potential.

\section{INTRODUCTION}

The Khadum and Batalpashin sediments of the Maikop series, which include hydrocarbon $(\mathrm{HC})$ accumulations in the Fore-Caucasus, are represented both by conventional and low permeability shale reservoirs. The petrology calls oil and gas shales a whole series of solid, multi-layer pelite rocks: clays, marls, clayey limestones, argillites, siltstones and shales proper, which all contain various forms of 
organic matter, reflecting the stages of its maturity. An important distinctive feature of accumulations in shales (shale reservoirs) and in tight reservoirs is that hydrocarbons are in the dispersed state in rocks of low matrix permeability ${ }^{1}$. Oil and gas in such rocks are mostly in the diffused dispersed state in microfractures. At that, they do not depend on structural, stratigraphic, lithological and other conventional factors. For the oil-gas systems in low permeability shale reservoirs within oil and gas source rocks the fluid seals restricting the sequence are as a rule positioned on top and at the bottom of them.

The oil in tight rocks (tight oil) also includes oil accumulations in low permeability rocks, which are not necessarily shales, for instance, clayey limestones, limestones or sandstones with low petrophysical parameters and considered unconventional.

Geochemical studies showed that the organic matter in shales of low permeability reservoirs is often relatively immature and is at the stage of early oil generation. In such beds that did not reach sufficient subsidence depth and temperature peak also occur the generation of hydrocarbon organic matter. The formation pressure in such oil and gas source beds is insufficient to perform the internal hydrofracturing and to release hydrocarbons

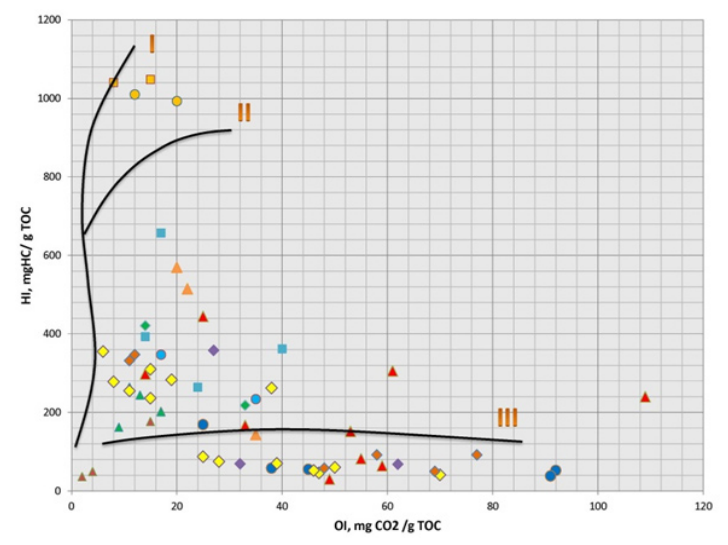

Wells:

$\checkmark$ Vorob'evskaya 2

$\Delta$ Vorob'evskaya 48

Karanogajskaya 6

- Achikulakskoe 56

Fig. 1: Modified Van Krevelen diagrams - correlation hydrogen index HI vs. oxygen index OI (a) and correlation of hydrogen index $\mathrm{HI}$ vs. maximum pyrolysis temperature $\mathrm{T}_{\mathrm{max}}$

from the mother bed. However, at conducting the artificial hydrofracturing they may be of potential interest. At that, the major criterion for exploration and appraisal of shale hydrocarbons is not a trap where hydrocarbons are accumulated and the accumulations form, but directly rock volumes, in which the $\mathrm{HC}$ formed but from which they have not emigrated yet. Their concentration in a bed depends on the in situ generation conditions.

\section{MATERIALS and METHODS}

\section{Geochemical studies of the organic matter}

Along with summarizing the results of previously conducted laboratory studies was conducted integrated study of core and cutting samples including chemico-bituminological, pyrolitic and coal petrography analyses. Overall 115 samplers of the Khadum sediments from 33 fields (structures) of the Eastern and Central Fore-Caucasus were analyzed by various techniques.

For the study of the organic matter was used the pyrolitic technique Rock-Eval (a method of direct detemination of rock hydrocarbon potential and organic matter and also the extent of its realization and oil-gas-generation zones (the level of rock maturity).Pyrolitic studies were conducted in the oil shales geochemistry laboratory of the RGU (Gubkin

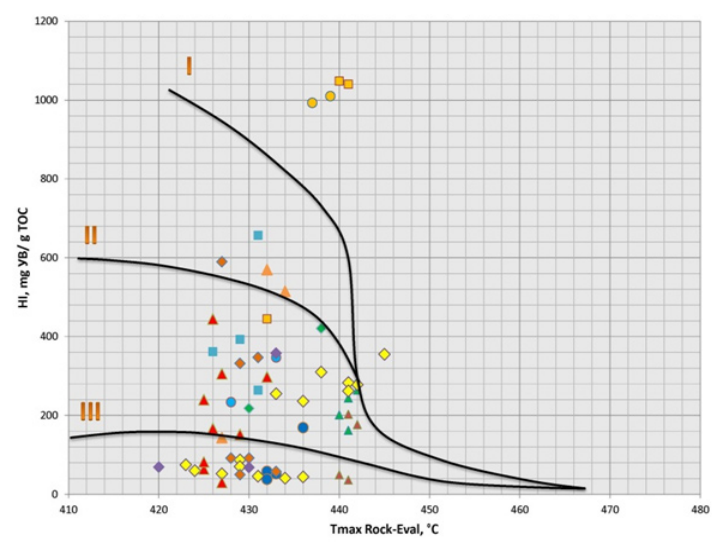

$\square$ Vorob'evskaya 15

- Karanogajskaya 1

-Yuzhno-Ozek-Suat 11
A Vorob'evskaya 43 - Karanogajskaya 2 A Belozerskaya 14
- Yuzhno-Spasskaya 7

- Polevoe 3 
Russian State University) of oil and gas in the name of I.M. Gubkin using the equipment Rock-Eval 6 (VINCI Technologies).

The heat maturity is among the most important parameters for the evaluation of oil shale deposits.A commonly used parameter of rock organic matter heat maturity is vitrinite reflectance $\left(\mathrm{VR}_{\mathrm{o}}\right)$. For its detemination was utilized a work station based on the binocular microscope Àxio Scope A1 for optical studies in reflected light and luminescent light and for the conduct of quantitative detemination of coal macerals in the reflected light, in particular for the detemination of the vitrinite reflectance and also for the detemination of the organic matter type from luminescent glow.

Coal petrography studies were conducted with QD1302 equipment (manufactured by CraicTechnologies) in the laboratory of coal deposits at the Moscow M.V. Lomonosov State University. Coal petrography studies were conducted in 4 polished sections under the white light and included standard descriptions and measurements of the vitrinite reflectance - $\mathrm{RV} \%$, and also observations under the UV light.

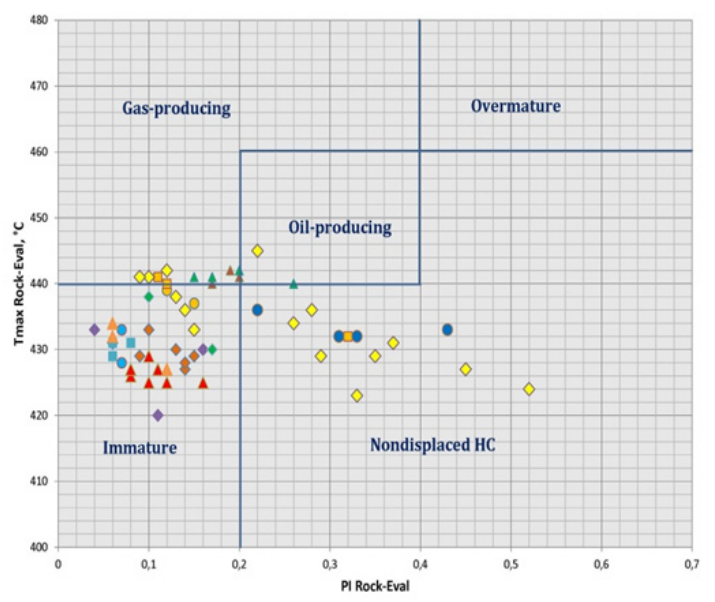

Wells:

$\diamond$ Vorob'evskaya 2

$\Delta$ Vorob'evskaya 48

Karanogajskaya 6

- Achikulakskoe 56

Fig. 2: Correlation diagrams of maximum pyrolysis temperature $T_{\max }$ vs. productivity index PI (a)
Zoning of the Khadum and Batalpashin Formations' distribution is based on the analysis and systematization of geochemical information by way of constructing maps of significative geochemical parameters' areal variation in the studied rocks in consideration of geologo-geophysical, lithological and other parameters. Map construction was conducted using the Schlumberger Petrel program package by the isochoric interpolation within the continental portion of the Stavropol, Eastern ForeCaucasus and Tersk-Caspian oil and gas provinces. The size of the grid cell was selected at $500 \times 500$ $\mathrm{m}$. The algorithm was tuned so that maximum and minimum values of parameters as a result of map construction would not exceed $10 \%$ of the initial extreme (maximum and minimum) values. At the final stage, the construction was conducted through several iterations of smoothing.

The evaluation of the Maikop Formation's Khadum and Batalpashin sediments generative potential in the region under study was based on results of pyrolitic analyses and created distribution maps of basic geochemical parameters: organic matter content, catagenesis degree $\left(\mathrm{T}_{\text {max }}\right)$, realized, residual and total organic matter generative potential

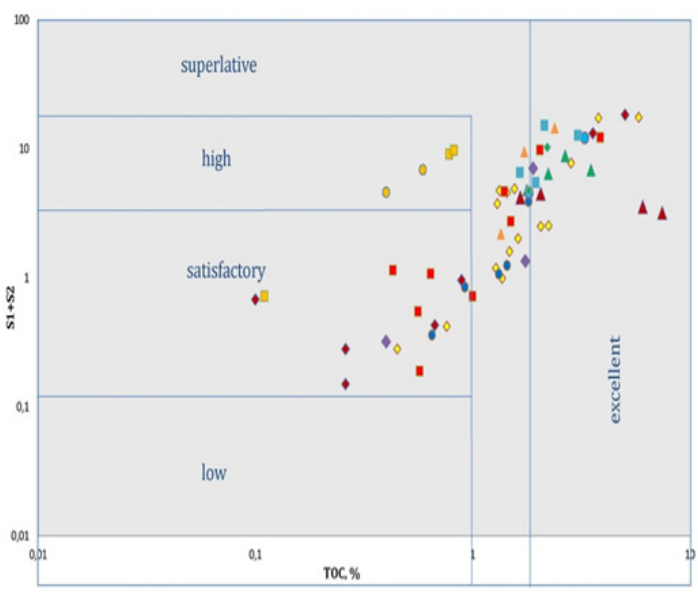

$\square$ Vorob'evskaya 15

- Karanogajskaya 1

(11

Yuzhno-Spasskaya 7

Yuzhno-Ozek-Suat 11

Karanogajskaya 2

$\Delta$ Belozerskaya 14
$\Delta$ Vorob'evskaya 43

\section{and of source rock generative potential vs. total content of the organic carbon TOC (b).}




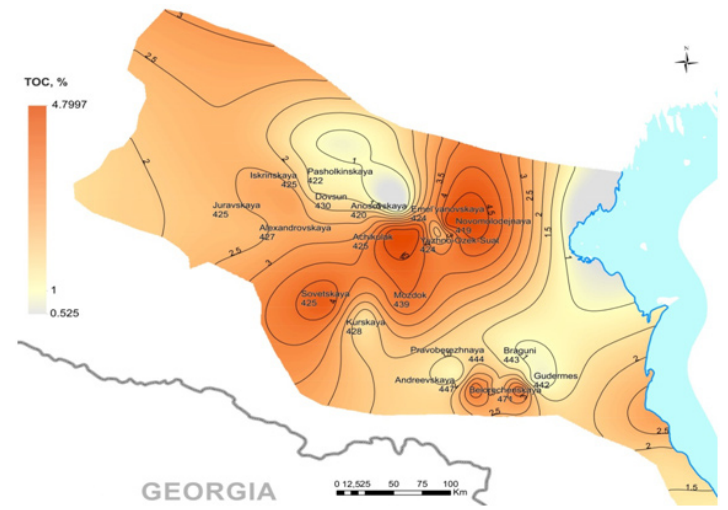

a

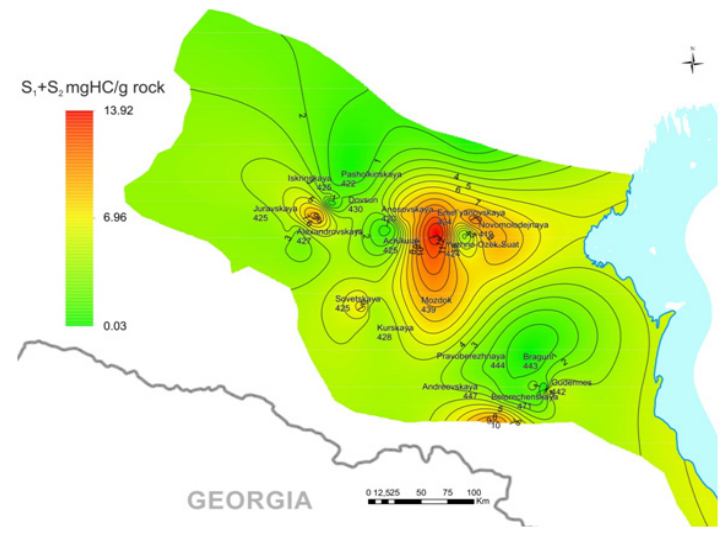

C

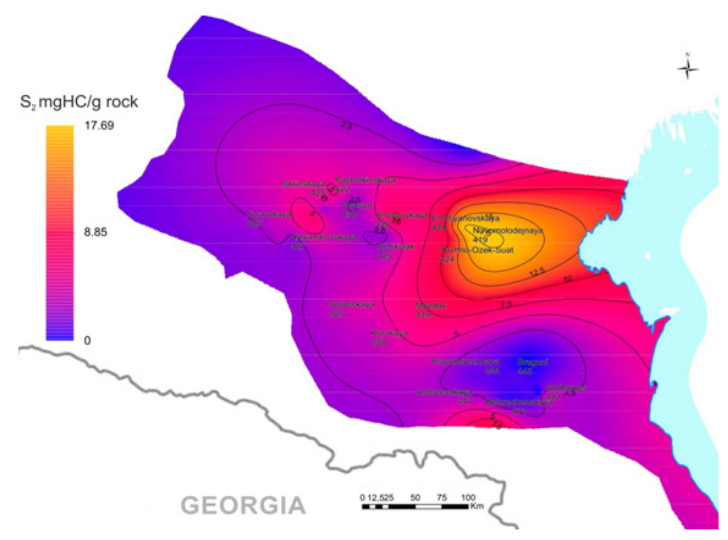

e

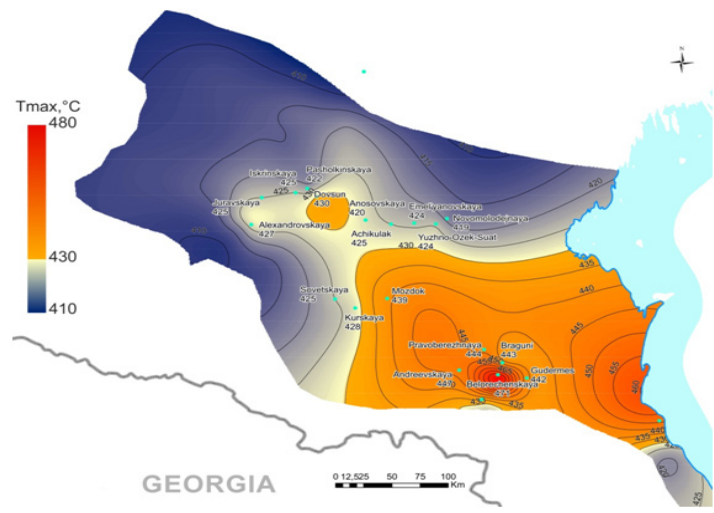

b

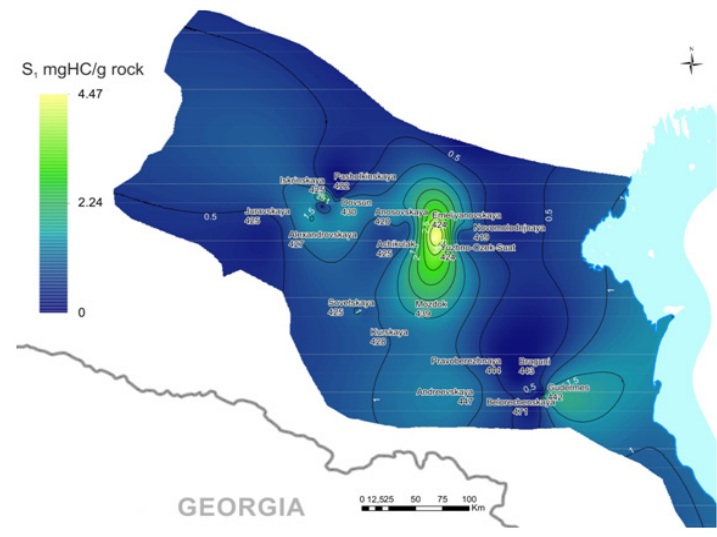

d

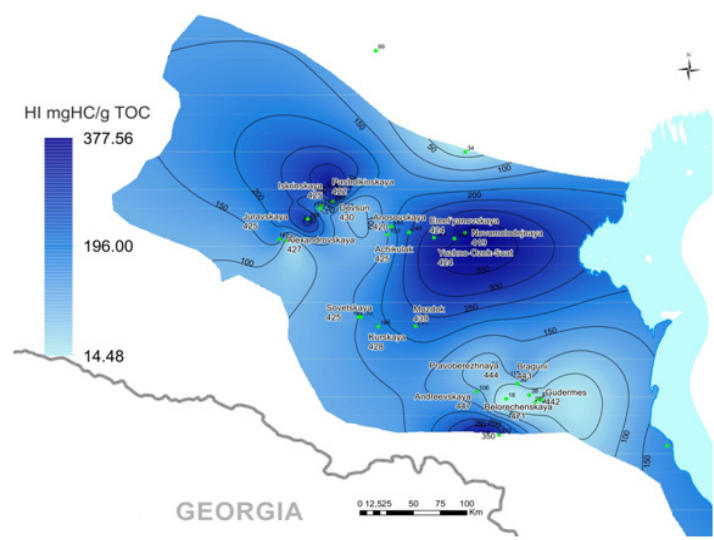

$\mathbf{f}$

Fig.3: Geochemical parameters' distribution map in the Khadum Formation of the Central and Eastern Fore-Caucasus: a. TOC concentration, $b . \mathrm{T}_{\max }$ values, $c$. Total generative potential $\left(S_{1}+S_{2}\right), d$. Realized generative potential $\left(S_{1}\right)$, e. Residual generative potential $\left(\mathrm{S}_{2}\right)$, f. Hydrogen index $(\mathrm{HI})$. 
$\left(\mathrm{S}_{1}, \mathrm{~S}_{2}\right.$ and $\left.\mathrm{S}_{1}+\mathrm{S}_{2}\right)$ and hydrogen index $(\mathrm{HI})$. The calculations were conducted for the three identified oil and gas provinces (Eastern Fore-Caucasus, Stavropol and Tersk-Caspian) for sediments of the Khadum Formation and for Eastern Fore-Caucasus oil and gas province, for the Batalpashin sediments $\mathrm{s}^{2-5}$. In the identified zones were estimated the volume and mass of oil and gas source rocks for the Khadum and Batalpashin sediments. For the estimations were applied averaged values of sediment thickness, rock density and specific generative potentials of the organic matter.

\section{Study results}

Based on pyrolitic studies, the Khadum and Batalpashin sediments display quite high generative potential values.

The content of free hydrocarbons $\left(S_{1}\right)$ describes the value of realized generative potential. It varies within $0.04-9.44 \mathrm{mg}$ of $\mathrm{HC}$ per a gram of rock. Maximum values are recorded in marls of the Morozkin ravine sub-formation on the Emelyanov structure (depth 2,427 m). Maximum $\mathrm{S}_{1}$ values are typical of the Khadum sediments in the Chernoles depression and Kuma swell (Emelyanov, Iskrin, Zhuravskay, Achikulak, Ozek-Suat); and minimum, for the Karpinsky Ridge (Elista, Black Earth).

Contents of HC kerogen and resinasphaltene compounds pyrolysis products (describing residual generative potential $\mathrm{S}_{2}$ ) vary within even greater value range of $0.18-47.77$

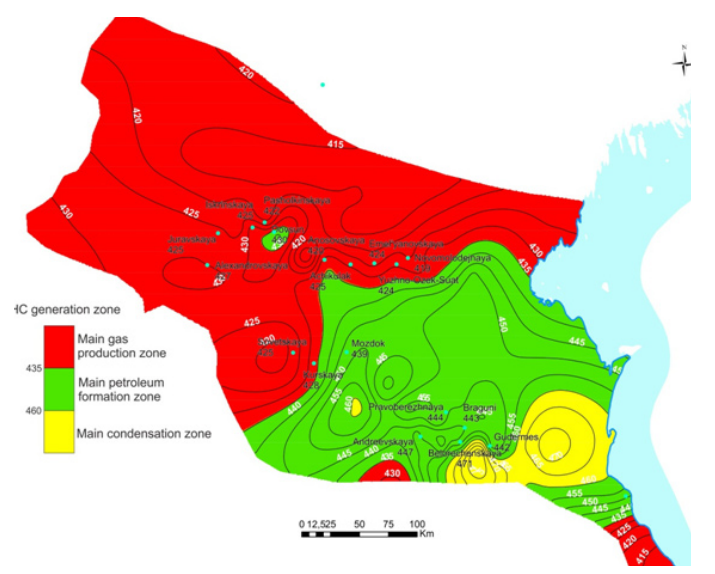

Fig. 4: Zoning schematics of hydrocarbon generative zones in the Khadum and Batalpashin sediments. mg HC per a gram of rock. The spatial pattern in variations of $S_{2}$ concentrations is substantially similar to $S_{1}$ distribution pattern The highest values are noted in the Khadum sediments (especially in the samples of the Ostracod horizon) of the Kuma swell (Ozek-Suat, Achikulak, Novomolodezhnaya and Emelyanov), Eastern plunge of the Stavropol Arch (Alexandrov, Zhuravsky) and north flank of the Tersk-Caspian Trough (Sovietskaya, Kurskaya). Maximum $\mathrm{S}_{2}$ values $(47.77 \mathrm{mg} \mathrm{HC}$ per a gram of rock) are established also in marls of the Ostracod horizon in the Emelyanov prospect.

Average value of total generative potential $\left(\mathrm{S}_{1}+\mathrm{S}_{2}\right)$ for the studied samples (Khadum and Batalpashin Formations) is $4.83 \mathrm{mg}$ of $\mathrm{HC}$ per a gram of rock. For the Batalpashin rocks average value of total generative potential is $1.62 \mathrm{mg} \mathrm{HC}$ per a gram of rock, for the Khadum $-7.85 \mathrm{mg} \mathrm{HC}$ per a gram of rock. The scatter of the total generative potential is quite broad, 0.3 to $50.89 \mathrm{mg} \mathrm{HC}$ per a gram of rock. Maximum values of $S_{1}+S_{2}$ are recorded for sediments of the Ostracod sub-formation in the Kuma swell zone. The development zone of the Khadum and Batalpashin oil and gas source rocks with high generative potential encompasses the Kuma swell and Chernoles depression. According to Tissot and Welte (1981) classification, the Khadum sediments may be attributed to an oil and gas source rock category with high generative potential $\left(\mathrm{S}_{1}+\mathrm{S}_{2}>6 \mathrm{mg} \mathrm{HC}\right.$ per a gram of rock) and the Batalpashin, to a gas source rock category of low potential.

Genetic and catagenic organic matter parameters are illustrated by various correlation diagrams of such pyrolitic parameters as HI, OI, $\mathrm{S}_{1}+\mathrm{S}_{2}, \mathrm{~T}_{\text {max }}^{\circ}$, TOC, etc. One of them is the correlation diagram of the hydrogen index (HI) vs. $\mathrm{T}_{\text {max }}^{\circ}$. This graph, in essence, is modified Van Krevelen diagram. Not only does it enable the identification of different type kerogen fields but also allows to follow their catagenic evolution $^{6-7}$.

On the modified Van Krevelen diagram (Fig.1a) the kerogen of studied samples is within the field of IInd and IIIrd types. Both hydrogen and oxygen indices demonstrate broad variability. The rock samples enriched in the organic matter are positioned between II and III types of the organic 
matter. Only a small fraction of core samples from studied wells belongs to type I. Significant part of the samples, however, is represented by the organic matter of type IV and is in the non-generative area.

Rock samples with the highest oxygen index parameters take minimum content in the organic component (type IV kerogen). This suggests their high oxidation degree and increased fraction of formation of the inorganic $\mathrm{CO}_{2}$ due to decomposition of a calcareous matrix. Parameters of maximum pyrolysis temperature $\mathrm{T}_{\max }$ and of productivity index $\mathrm{PI}(\mathrm{S} 1 /(\mathrm{S} 1+\mathrm{S} 2))$ also support the thermal maturity of II and III type core samples. The correlation diagram $\mathrm{HI}$ vs. $\mathrm{T}_{\max }$ (Fig.1b) shows that the samples capable of generating hydrocarbons are in the zone of $\mathrm{T}_{\max }$ $435-445 \mathrm{C}^{0}$.and that the organic matter is mature. Out of 16 analyzed wells only 6 (all of them Vorobyev) are represented by thermally mature kerogen samples.

According to J. Espitalier and K.Peters ${ }^{8}$, the intervals containing liquid oil or high concentration of mobile bitumoid, show abnormally low values of pyrolysis temperature $T_{\text {mào }}$. Most of the derived $T_{\max }$ values are within $425-433^{\circ} \mathrm{C}$, which is traditionally associated with the beginning of the "oil window" - catagenesis grade $\mathrm{PK}_{3}-\mathrm{MK}_{1}$, and low $\mathrm{T}_{\text {mào }}$ values emphasize migration nature of the bitumoid.

At such temperature the degree of organic matter catagenic maturity is quite low. Despite insignificant organic matter maturity degree, perhaps, generation of hydrocarbons by the organic matter is already occurring, which is indicated by elevated content of $\mathrm{S}_{1}$ (appearance of parautochthonousbitumoids) in samples. For mature samples in the value range of pyrolitic parameter $\mathrm{T}_{\max }-440-452^{\circ} \mathrm{C}$, catagenic maturity of the organic matter corresponds with the middle and final stages of the «oil window» $\mathrm{MK}_{2}-\mathrm{MK}_{3}$.

In the diagram $T_{\text {max }}=f(P I)$ (Fig.2-a) rock samples are positioned in the province of immature organic matter. The organic matter catagenic maturity degree is quite low. The $T_{\max }$ values vary within insignificant range, the lowermost values are typical of migration bitumoids. Most values are within 425$433^{\circ} \mathrm{C}$, which corresponds with the beginning of the «oil window». This is also supported by insignificant productivity index, up to 0.20 . An increase in the productivity index $\mathrm{PI}$ values to 0.52 at low $\mathrm{T}_{\max }$ values demonstrates migration nature of the bitumoid.

The reviewed samples indicate that the source rocks have oil and gas generative potential. Some of them (wells Vorobyev 2, Andreyev 1016, Gudermes 200) are within the oil generation zone («oil window»).

Thus, as the study results show, the formation of oil accumulations occurred due to early generation of liquid hydrocarbons byimmature oil source rocks (wells Vorobyev 2, Vorobyev 11, Vorobyev 15, Vorobyev 43, Karanogay 1, Karanogay 2, Karanogay 6, Polevoye 3, South Ozek-Suat 11, Belozer14.,Achikulak 56). This resulted in the formation of the so-called immature crude oil. As is seen in diagram 2à, a significant part of rock samples include immature organic matter, which affects the composition of crude oils forming from it. They are usually heavy crudes, polycyclic, enriched in highmolecular and heteroatomic compounds. They are

Table1: Quantitative evaluation of the initial generative hydrocarbon potential for the Khadum sediments in the Central and Eastern Fore-Caucasus

\begin{tabular}{lccc}
\hline Parameters & $\begin{array}{c}\text { East Fore-Caucasus } \\
\text { and gas province }\end{array}$ & $\begin{array}{c}\text { Stavropol oil } \\
\text { and gas } \\
\text { province }\end{array}$ & $\begin{array}{c}\text { Tersk-Caspian } \\
\text { oil and gas } \\
\text { province }\end{array}$ \\
\hline $\begin{array}{l}\text { Mass of oil and gas source } \\
\text { rocks, billion ton }\left(\mathrm{M}_{\text {rock }}\right),\end{array}$ & 10,032 & 7,229 & 5,098 \\
$\begin{array}{l}\text { Average specific generative } \\
\text { potential value }\left(\mathrm{S}_{\text {spec }}\right) \text {, ton/ton }\end{array}$ & 0.0046 & 0.00324 & 0.00455 \\
$\begin{array}{l}\text { Total initial generative } \\
\text { potential }\left(\mathrm{P}_{\text {init. khad. }}\right) \text {, billion tons }\end{array}$ & 46.1 & 23.4 & 23.2 \\
\hline
\end{tabular}


lacking in low molecular weight alkanes, include long-chained cyclanes and have low degree of aromaticity. For the crudes in Oligocene sediments of the Eastern Fore-Caucasus, monotonous in the stratigraphic section, are typical immature varieties.

Typical for such crudes are somewhat elevated density $\left(0.85 \mathrm{~g} / \mathrm{cm}^{3}\right.$ and higher $)$, the silica gel resin content of $9.0 \%, 1.5 \%$ and more asphaltenes. By the paraffin content ( $11 \%$ and up) the crudes are classified as high-paraffin. Relatively high crude density is caused by the presence of resin-asphaltene components and solid paraffin substances (Kudin, E.V., 2013).

Fig. $2 b$ is a correlation diagram of the source rock generative potential vs. total organic carbon content. The correlation diagram of total (oil and kerogen) potential $S_{1}+S_{2}=f(T O C)$ allows including the significant part of rock samples among rich and very rich. Under the standard classification quality of oil and gas source rocks in the studied wells varies between poor and very rich. For instance, the rock samples from wells Karanogay 1, Karanogay 6, Karanogay 4, Karanogay 2, Vorobyev 43, Vorobyev 50 , South Ozek - Suat 11, Belozer 14. Gudermes 200, Iskrin 5, Dovsun 4. Novomolodezhnaya 3, Kurskaya 10. Belorechen 78, Achikulak 65, OzekSuat 5 are described as very rich, wells Vorobyev 2, Vorobyev 11, Vorobyev 15, Vorobyev 43, Vorobyev 48, Vorobyev 50 . South Spasskaya 7, Karanogay 4,

\section{Table 2: Quantitative evaluation of the initial generative hydrocarbon potential for the Batalpashin sediments of the Central and Eastern Fore-Caucasus}

\begin{tabular}{ll}
\hline Parameters & East Fore-Caucasus \\
oil and gas province
\end{tabular}

\begin{tabular}{lc}
$\begin{array}{l}\text { Macca oil and gas source } \\
\text { rocks, billion tons }\left(\mathrm{M}_{\text {rock }}\right)\end{array}$ & 22,003 \\
$\begin{array}{l}\text { Average value of the specific } \\
\text { generative potential }\left(\mathrm{S}_{\text {spec }}\right),\end{array}$ & 0.00185 \\
ton/ ton & \\
$\begin{array}{l}\text { Total initial generative } \\
\text { potential }\left(\mathrm{P}_{\text {init. bat. }}\right), \text { billion tons }\end{array}$ & 40.7 \\
\hline
\end{tabular}

Karanogay 6, Anosov 1, Polevoye 3, South OzekSuat 11, Belozer 14, Achikulak 56, Alexandrov 5, Iskrin 5, Sovietskaya 19, Kurskaya 10, Khankala 7, North Mineralnaya 16, Braguny 91, Andreyev 1016, Achikulak 65 as rich, well Karanogay 6 as satisfactory, wells Karanogay 1, Karanogay 6, Vorobyev 15, Vorobyev 2 as poor.

The results of coal petrography studies (measurements of vitrinite reflectance parameter) were studied in samples from wells Alexandrov 5, Ozek-Suat 5, Sovietskaya 19 and Kurskaya10. The organic matter (OM) particular feature in the studied samples is general low organic matter content and the absence of those macerals, which are used for measuring $\mathrm{RV}$, \%

The organic matter is represented mostly by bitumen films, often small, intergranular. In the OzekSuat-5 samples of these films are more common and form extensive interlayer laminae reminding channels. In a sample from Sovietskaya 19 beside bitumen films are found shaped liptinitemacerals very brightly luminescing under the UV light. More accurate diagnostic of the liptinites is difficult as their morphology is not obvious (that may be remnants of algae, resinites and sporinites ${ }^{9-12}$ ).

Fragments of vitrinite $(\mathrm{Vt})$, redeposited along with other rock fragments, are very rare and small. RV measurements, \%, were performed in samples of Ozek-Suat-5. The histogram is not representative as it demonstrates large scatter of RV values, \%. The RV values greater than $0.75 \%$ belong directly to vitrinite bearing the information of the erosion zone and the $\mathrm{RV}$ values $<0.30 \%$ are determined in the sapropel type amorphous organic matter. Such parameters could be used as «vitrinite equivalent», with appropriate recalculation. Numerous scientists proposed reflectance measurement recalculation formulas for the measurements in «vitrinite equivalent» (in our case in the residual organic matter or solid bitumens). Most common may be the following formulas:

1994),

$$
\text { VRo }=0.668 \cdot \text { BRo }+0.346 \text { (Liu\&Shi, }
$$

$$
\text { VRo }=0.668 \cdot \text { BRo }+0.40(\text { Jacob, 1985) }
$$


According to the calculations, for the analyzed sample VRo $=0.668 \cdot 0.28+0.40=0.59(\%)$, where $0.28 \%$ is the actual measurement for the residual organic matter; $0.59 \%-\mathrm{RV}_{\text {equiv }}$ value.

The organic matter behavior under the UV light may be used for the evaluation of catagenesis degree as an additional parameter. Liptinitemacerals generating liquid $\mathrm{HC}$ usually luminesce «before» and during oil generation. At high catagenesis stages no organic matter luminesce. The luminescence is observed in shaped liptinite components, in bitumen films and clots (the sample Kurskaya 10).

Considering the accumulated world experience ${ }^{13-14}$ in the study of «shale» formations (Formations Barnett, Marcellus, Haynesville, Eagle Ford, etc.), the following geochemical parameters are determined as most significative and defining the hydrocarbon potential of the «shale» sequences: the type,content and catagenesis degree of the organic matter.

\section{The organic matter type}

According to the data by various authors, the Khadum and Batalpashin sediments in the study region include the organic matter of three morphological types: dispersed-scattered, humus-like amorphous and coaly (Fadeyeva et al., 1998, 1999). Finely dispersed organic matter is highly dominant, the fraction of other varieties is insignificant. The shape of humus-like organic matter type is filamental, oblong, lens-shaped and fragmentary. The coaly type organic matter is recorded as grains of mostly aleurite (silt) dimension (Fadeyeva, Bazhenova, SaintGermes, 2002). In carbonate interbeds are rarely encountered coaly inclusions of up to $1 \mathrm{~mm}$ in size. N.M. Strakhov (1954. 1957, 1961), K.F. Rodionova (1954, 1959), V.V. Weber (1956) and a number of other scientists established that the dispersed shape of the organic matter is usually appropriate to clean clayey varieties. In rocks with some amount of clastic material the «humus-like» organic matter is recorded.

Based on the results of chemicobituminological studies, the Khadum and Batalpashin sediments are distinct in high content of bitumoids. Bitumoid texture is mostly uniform, rarely lensshaped. The luminescence nature of rocks, bitumoid solutions and their capillary extracts indicates the presence of only light (LBA) and oily (MBA) bitumoids.

The content of chloroform (ChB) and alcohol-benzene (DSBB) bitumoids in rocks is 0.01 $1.5 \%$. Higher bitumoid concentrations are noted in the rocks of the Pshekh sub-formation (ChB- $0.74 \%$, DSBB - 0.44), in sub-formation of the Morozkin ravine $\mathrm{ChB}-0.52 \%$, DSBB $-0.3 \%$, in the Batalpashin Formation ChB $-0.35 \%$, DSBB $-0.27 \%$.

The total balance of bitumoids in all lithological sediment varieties studied within the Eastern Fore-Caucasus is dominated by ChB. The ratio ChB/DSBB in rocks of Zhuravskaya and Praskovey structures varies between 0.22 and 3.5 (average is about 1.4). ChB/DSBB ratio in rocks on the South Ozek-Suat structure is 1.04 to 9.4 . On the Sovietskaya structure (where the Oligocene sediments are significantly deeper and more mature), the ChB/DSBB ratio reaches 13.8 (average 4.5) (Goryagina, 2005). The ChB group composition includes on average: lubricants $-57.5 \%$, resins - $39.3 \%$, asphaltenes $-3.2 \%$. ChB elementary composition is: $\mathrm{C}-82.3 \%, \mathrm{H}-10.2 \%,(\mathrm{O}+\mathrm{N}+\mathrm{S})$ $-7.5 \%$.

In sandstone-siltstone-clayey rocks of the Central Fore-Caucasus no excess of ChB over DSBB content is established, which indicates the oxidized nature of bitumoids. The $\mathrm{ChB}$ content in the Khadum clays of the Central Fore-Caucasus is 0.015 $0.04 \%$. On the Sengileyev structure, where the clays include siltstone interbeds, the oily bitumoid content ranges between 0.017 and $0.04 \%$. The bitumoid concentration in siltstones and sandstones of the Rashevat structure is $0.002-0.015 \%$ (Rodionova, Maximov, 1981; Rodionova, Starovoytov, Kiriyenkova, 1958).

The Oligocene sediments of the Central and Eastern Fore-Caucasus also substantially differ in the content of the organic matter humic acids. Thus, the organic matter of clayey rocks in the Central Fore-Caucasus contain $0.33-1.67 \%$ of humic acids (Gimpelevich, 1958; Rodionova, Starovoytov, Kiriyenkova, 1958). A specific feature of the organic matter in clayey sediments of the Eastern ForeCaucasus is total absence of humic acids caused by 
their decomposition in the process of organic matter catagenesis.

Thus, the quoted geochemical data indicate that the Khadum and Batalpashin sediments in the study territory include mixed organic matter. The ratio of humic and sapropel components in the organic matter in different areas noticeably varies (Mikhaylov, 2003). It is established that more «noble», mostly sapropel composition of the organic matter is typical of the Oligocene sediments in the Eastern and Southeastern parts of the Eastern Fore-Caucasus (eastern portions of the East Manych Trough, Kuma swell, Nogay Step; central and eastern portions of the Tersk-Caspian Trough), and also of the northwestern Stavropol Arch. V.N. Mikhaylov (2003) indicated that the fraction of the sapropel component in the organic matter of eastern areas of the Eastern Fore-Caucasus reaches $90 \%$.

Sapropel-humic organic matter type (humic component reaches $70 \%$ ) is typical of the rest, larger portion of the Stavropol Arch and adjacent areas of the Eastern Stavropol depression, Nogay Step and western portions of the Kuma swell and TerskCaspian Trough.

The organic matter content.According to chemico-bituminological studies by various authors, the TOC content in samples of the Khadum sediments varies between $0.26 \%$ (Pshekhlimestones in well Dovsun 4 well) and 8.35\% (Ostracod horizon clays in well Emelyanov 1). Modal TOC value for all studied samples (226 samples) is $2.11 \%$. Average value of the TOC content for rocks in the Batalpashin Formation is 1.41 , in the Khadum $2.26 \%$. Increasing degree of rock content carbonatisation lowers the TOC. Minimum values are recorded in limestone organic matter $(0.25 \%)$. The highest $\mathrm{C}_{\text {org }}$ average values are typical of clays and marls in the Ostracod horizon- $4.46 \%$.

The TOC concentration variation pattern over the study area is shown in Figs. 3a. The maps show that the zone of maximum TOC values (greater than 3-4\%) extends diagonally from the northwestern centroclinal of the TerskCaspian Trough (Sovietskaya, Kurskaya structures) northeasterly toward the East Manych Trough through the central part of the Kuma swell (Achikulak,
Emelyanov, Novomolodezhnaya structures). Some local maximums of the TOC concentration (about $2-3 \%$ ) are recorded in the eastern areas of the TerskSunzha folded zone (Oktyabrskaya, Khankalskaya structures) and Piedmont Dagestan (Dimitrtovskaya structure).

According to the classification by K.E. Peters (1986) ${ }^{15}$ and geologists from Institutfrançais du pétrole (IFP), the Khadum and Batalpashin sediments in the Eastern and Central Fore-Caucasus may be described as mostly «rich» (TOC $\geq 1-3 \%)$ and «very rich» (TOC>3\%) oil source rocks.

The development area of "very rich" Khadum oil and gas source rocks crosses the study region as a narrow diagonal band from the southwest to northeast. The TOC values reach there $4 \%$ and greater. Some local areas of «very rich» Khadum oil source rocks are also recorded within the TerskSunzha zone. Over the most of the study territory the studied sediments may be attributed to a class of «rich» oil source rocks.

Only locally (northwestern framework of the Stavropol Arch, western framework of the Caspian Sea, western part of the Sulak depression) the studied sediments are classified as «average» oil source rocks in terms of the $\mathrm{C}_{\text {org }}$ content (less than 1\%).

\section{Organic matter catagenesis degree}

The catagenic maturity of the rock organic matter is among the most important parameters used for oil and gas occurrence forecasting. Major factors causing catagenic alterations of rocks and organic matter are formation temperature and geologic time. The formation pressure can also indirectly affect the development dynamics of catagenesis processes in «closed» hydrocarbon systems. Some scientists (Taranenko et al., 1992) believe that in thick clayey sequences the impeded outflow of generated waterhydrocarbon products (causing significant increase in the formation pressure) is capable of slowing down processes of the organic matter maturation.

Areal variations in the catagenesis degree of the studied sediments are shown in the maps of $\mathrm{T}_{\max }$ values and of generative zones' evolution (Fig. 3b).Due to practically total absence in finely 
dispersed Oligocene sediments in the studied region of high quality vitrinite remains, the evaluation of the organic matter degree of catagenesis was conducted based on the derived values of a pyrolitic parameter $\mathrm{T}_{\text {max }}$.

The maps clearly show that the zone of the highest $\mathrm{T}_{\max }$ values covers the central part of the study region. Tectonically, this part of the region includes eastern portions of the Kuma swell and Nogay Step, and also the central and eastern portions of the Tersk-Caspian Trough. Within this zone the Khadum sediments' $\mathrm{T}_{\max }$ values as a rule exceed the level of $430^{\circ} \mathrm{C}$ forming the lower boundary of the "oil window». Maximum $\mathrm{T}_{\max }$ values (up to $470^{\circ} \mathrm{C}$ ) are recorded within the most subsided areas of the Tersk-Caspian Trough (Belorechen, Bragun, Pravoberezhnaya, Gudermes).

The western and northern parts of the territory (Stavropol Arch, adjacent western parts of the Kuma swell, East Stavropol depression, East Manych Trough) display a low level of the Oligocene sediments' catagenic maturity (not reaching the grade of mesocatagenesis, i.e., in the zone of immature kerogen). $\mathrm{T}_{\max }$ values there do not exceed the level of $430^{\circ} \mathrm{C}$.

The lowermost $\mathrm{T}_{\max }$ values (around $420^{\circ} \mathrm{C}$ ) are recorded in the central part of the Stavropol Arch and uplifted areas of the South Dagestan (southeastern part of the Tersk-Caspian Trough).

Within the Central Fore-Caucasus and adjacent areas of the Eastern Fore-Caucasus, the Khadum sediments are altered to the grade of protokatagenesis, i.e., they are positioned in the environment of the upper zone of gas generation. In the most uplifted southeastern portion of the TerskCaspian Trough, within the South Dagestan the Khadum sediments are also within the upper zone of gas generation (Fig. 4)

The evaluation of the generative potential was conducted using geochemical parameters. Results of the pyrolitic studies and utilization of geochemical parameters of the Khadum and Batalpashin sediments enabled the evaluation of generative potential for the studied sediments based on the principles of the modern depositional- migrational theory of the oil origin. According to this theory, oil is generated as a result of kerogen destruction in the organic matter, and oil and gas occurrences in the basin are caused by the following major processes: the accumulation of initial organic matter in the subaquatic sediments, organic matter alteration at the stage of lithogenesis (first of all, catagenesis) and the formation of hydrocarbons, their migration and accumulation in the natural reservoirs (I.O. Brod, N.B. Vassoyevich, S.G. Neruchev, etc. ${ }^{16-}$ 18.

Fig. 3a shows that the highest organic matter concentrations in the Khadum sediments are recorded within a diagonal zone extending from Sovetskaya structure in the southwest to Emelyanov structure in the northeast. The TOC values there reach $4 \%$ and greater. Some local maximums of the TOC value $(3-4 \%)$ are recorded in the eastern areas of the Tersk-Sunzha zone (Belorechen, Khankal, Gudermes) and in the Piedmont Dagestan (Dimitrovskaya). It must be noted that at TOC concentrations $\geq 2 \%$ the oil source rocks are classified as high or very high quality.

Spatial patterns in the variations of catagenesis degree for the studied sediments are reflected in the map of $\mathrm{T}_{\max }$ values (Fig. $3 \mathrm{~b}$ ). The map clearly shows that over the most of the study territory the Khadum sediments are at the initial stages of the «oil window» $\left(\mathrm{T}_{\max } \geq 430^{\circ} \mathrm{C}\right)$. The highest catagenic maturity reaching the grade of middle mesokatagenesis $\left(\mathrm{T}_{\max }\right.$ of up to $470^{\circ} \mathrm{C}$ ) is registered in most subsided areas of the Tersk-Caspian Trough (Belorechen, Bragun, Pravoberezhnaya, Gudermes). Only in the most northern and northwestern parts of the territory (Podsolnechnaya, Ozek-Suat, Anosov, Severnaya, Alexandrov, Zhuravskaya, etc.) the Khadum sediments have low level catagenic maturity (not reaching the grade of mesocatagenesis - zone of the immature kerogen).

Generative capabilities of the Khadum sediments were evaluated from the $S_{1}, S_{2}, S_{1}+S_{2}$ parameters' distribution and hydrogen index $(\mathrm{HI})$ maps. The map of total generative potential $\left(S_{1}+S_{2}\right)$ value for the Khadum sediments (Fig. 3c) shows that these sediments display the highest hydrocarbon potential within the central part of the Kuma swell (Emelyanov, Achikulak, Ozek-Suat), the western 
portion of the Nogay Step, the northwestern flank of the Tersk-Caspian foredeep (Mozdok, Sovietskaya, Kurskaya) and the western part of the East Stavropol depression (Zhuravskaya, Iskrin). Maximum values $\left(S_{1}+S_{2}\right)$ there reach $13 \mathrm{mg} \mathrm{HC}$ per a gram of rock $\left(\left(S_{1}+S_{2}\right) \geq 6\right.$ indicates «oil source rocks of high generative potential»). Minimum values of the total generative potential are recorded on the Stavropol Arch and within the zone of Manych Trough (1-2 mg $\mathrm{HC}$ per a gram of rock - «oil source rocks of a low gas potential»).

Within the folded flank of the Tersk-Caspian Trough, the $\left(S_{1}+S_{2}\right)$ values are on average on the order of 2-3 mg HC per a gram of rock with a tendency of noticeable increase (up to $8-10 \mathrm{mg}$ $\mathrm{HC}$ per a gram of rock) southward (in the basin of Chanty-Argun River) and southeastward (up to $6 \mathrm{mg}$ $\mathrm{HC}$ per a gram of rock) in the Piedmont Dagestan («oil source rocks of moderate and high generative potential»).

Similar spatial variation patterns are typical also for the value of realized generative potential $\left(\mathrm{S}_{1}\right.$ - free HC's) (Fig. 3d). Maximum $\mathrm{S}_{1}$ values (up to $4 \mathrm{mg} \mathrm{HC}$ per a gram of rock) are also noted over the central portion of the Kuma swell (Emelyanov structure), poorer expressed local maximums (up to $2 \mathrm{mg} \mathrm{HC}$ per a gram of rock) are observed in the eastern part of the Tersk-Sunzha zone (Gudermes structure) and in the west of the East Stavropol depression (Zhuravskaya, Iskrin). Over the most of the study territory values of the realized generative potential are less than $1 \mathrm{mg} \mathrm{HC}$ per a gram of rock. That is an indication of both low initial generative potential and low degree of its realization.

Variations over the area of the residual generative potential value $\left(S_{2}\right)$ are notably different from the $S_{1}$ and $\left(S_{1}+S_{2}\right)$ variation picture. The map (Fig. $3 e$ ) shows that the province of maximum $\mathrm{S}_{2}$ values (up to $17 \mathrm{mg} \mathrm{HC}$ per a gram of rock and greater) encompasses the eastern part of the Kuma swell and possibly adjacent areas of the East Manych Trough and Nogay Step (where there are no data). According to Tissot and Welte (1981), oil source rocks with $S_{2} \geq 5$ belong to the class of «rich» oil and gas source formations.
Westward, toward the Stavropol Arch (Iskrin, Pasholkin, Zhuravskaya, Alexandrov structures) the $\mathrm{S}_{2}$ values are on average about 2-4 mg HC per a gram of rock. More to the south, within the Tersk-Caspian Trough, they vary within 2-3 mg HC per a gram of rock. Local maximums are recorded in the Argun River basin (greater than 8 $\mathrm{mg} \mathrm{HC}$ per a gram of rock) and within the Piedmont Dagestan (Dimitrovskaya - about $5 \mathrm{mg} \mathrm{HC}$ per a gram of rock). Minimum values (up to $1 \mathrm{mg} \mathrm{HC}$ per a gram of rock) are established within the Karpinsky Ridge (Black Earth, Elista).

The distribution value map of hydrogen index $(\mathrm{HI})$ is quite similar with the $\mathrm{S}_{2}$ map. This attribute also describes residual generative potential of the Khadum sediments (Fig. 3f). The areas of high $\mathrm{S}_{2}$ values correspond with the areas of highest hydrogen index values (250-350 mg HC per a gram of TOC).

Calculations of the initial generative potential were made using the technique developed in the French Institutfrançais du pétrole (IFP). The derived pyrolitic parameters $S_{1}$ and $S_{2}$ were utilized. The calculation technique is based on the idea of $S_{1}$ value corresponding with the amount of «free» $\mathrm{HC}$ per unit of mass (1 ton) of the source rock and $\mathrm{S}_{2}$ value corresponding with the potential (residual) hydrocarbon kerogen per mass unit of rock. The initial generative hydrocarbon potential was calculated from the equation: $P_{\text {init }}=S_{\text {spec }} \times M_{\text {rock }}$, where $P_{\text {init }}$ is total initial generative hydrocarbon potential, tons; $\mathrm{S}_{\text {spec }}$ is specific total generative hydrocarbon potential calculated as follows: $\mathrm{S}_{\text {spec }}=\mathrm{S}_{2}+\mathrm{S}_{1}$, tons $\mathrm{HC} /$ ton of rock; and $\mathrm{M}_{\text {rock }}$ is mass of rock of the entire oil source sequence, tons.

The calculated values of the initial generative hydrocarbon potential for the Khadum and Batalpashin sediments within the identified zones are included in Tables 1 and 2.

\section{Discussion of the results}

Integrated geochemical study of the organic matter by methods of bituminology, pyrolysis and coal petrography showed that in the Khadum sediments are developed all kerogen types with prevailing type II kerogen (mixed humic-sapropel organic matter with $\mathrm{H} / \mathrm{C}_{\mathrm{at}}{ }^{1}=1.1-1.5 ; \mathrm{HI}=300-700 \mathrm{mg} \mathrm{HC}$ per a gram 
of TOC). The fraction of other varieties is insignificant. Based on the complex of geochemical parameters (TOC, $\mathrm{HI}, \mathrm{S}_{1}+\mathrm{S}_{2}$ ), the Khadum sediments may be attributed to «rich» and "very rich» («outstanding») oil and gas source rocks. Most favorable geochemical attributes are found in rocks of the Ostracod subformation in the Khadum Formation. They are distinct in the highest $\mathrm{C}_{\text {org }}$ content, its more «noble» composition (I-II type of the matter) and the highest generative parameters $S_{1}, S_{2}, \mathrm{HI}$. The pyrolitic studies of the Khadum sediments revealed quite high values of the generative potential. Average value of the total generative potential $\left(S_{1}+S_{2}\right)$ in the studied samples (the Khadum and Batalpashin Formations) is 4.83 $\mathrm{mg} \mathrm{HC}$ per a gram of rock. The average value of total generative potential for the Batalpashin rocks is $1.62 \mathrm{mg} \mathrm{HC}$ per a gram of rock, for the Khadum, $7.85 \mathrm{mg} \mathrm{HC}$ per a gram of rock. Maximum $\mathrm{S}_{1}+\mathrm{S}_{2}$ values are recorded for sediments of the Ostracod sub-formation in the Kuma swell zone. A zone of the Khadum and Batalpashin oil and gas source rocks with high generative potential encompasses the Kuma swell and Chernoles depression (Emelyanov, Iskrin, Achikulak and Ozek-Suat structures). Over most of the study territory the Khadum sediments are in the beginning of the "oil window". In the north platform areas the degree of their catagenic maturity does not exceed the protocatagenesis grade. The maturity in the studied sediments within the region varies between protocatagenesis on the Karpinsky Ridge ( $\mathrm{T}_{\max }=390^{\circ} \mathrm{C}$ - Black Earth) to $\mathrm{MK}_{4}$ in the TerskCaspian Trough $\left(\mathrm{T}_{\max }=471^{\circ} \mathrm{C}\right.$ - Belorechen). For individual tectonic zones, the $T_{\max }$ value distribution looks as follows: the Tersk-Caspian Trough, 431$471^{\circ} \mathrm{C}\left(\mathrm{MK}_{1}-\mathrm{MK}_{4}\right)$; the Scythian plate, $412-447^{\circ} \mathrm{C}$ (PK-MK ${ }_{2}$ ); the Karpinsky Ridge, $390-435^{\circ} \mathrm{C}$ (PK$\left.M K_{1}\right)$. The highest maturity $\left(\mathrm{MK}_{2}-\mathrm{MK}_{4}\right)$ belongs to the Khadum sediments within the folded flank of the Tersk-Caspian Trough (Belorechen, Bragun, Gudermes structures).

The performed zoning of the Maikop series in the Fore-Caucasus by geochemical criteria showed that the Khadum and Batalpashin sediments over the major part of the study territory include mixed organic matter. At that, a more «noble» mostly sapropel organic matter (the fraction of the sapropel component reaches $90 \%$ ) is typical of Oligocene sediments in the eastern and southeastern portions of the Eastern Fore-Caucasus (eastern parts of the
East Manych Trough, of the Kuma swell, of the Nogay Step; central and eastern parts of the Tersk-Caspian Trough), and also in the northwest of the Stavropol Arch. By quantitative content of the organic matter, to the class of «very rich» (TOC $>3 \%)$ are attributed the Khadum and Batalpashin oil source sediments in a diagonal zone crossing the study region from southwest to northeast. Over the rest of the study territory the reviewed sediments are attributed mostly to the class of «rich» (TOC $\geq 1-3 \%)$ source rocks. The zoning by the degree of catagenic maturity in the studied sediments identified a zone of the highest $\mathrm{T}_{\max }$ values encompassing the central part of the study region (eastern portions of the Kuma swell and Nogay Step and also central and eastern part of the Tersk-Caspian Trough). Within this zone the $T_{\max }$ value of the Khadum sediments as a rule exceeds $430^{\circ} \mathrm{C}$. This level is the lower boundary of the "oil window». Maximum $\mathrm{T}_{\max }$ values (up to $470^{\circ} \mathrm{C}$ ) are recorded within most subsided areas of the Tersk-Caspian Trough (Tersk-Sunzha zone). The western and northern territory (the Stavropol Arch, the adjacent western portions of the Kuma swell, of the East Stavropol depression and East Manych Trough) has low level of Oligocene sediments catagenic maturity (not including the beginning grade of mesocatagenesis - zone of immature kerogen).

The evaluation of hydrocarbon initial geologic resources in the studied sediments was conducted on genetic basis. The «in situ» concept was used. According to this concept, the hydrocarbons generated in the Khadum and Batalpashin oil and gas source rocks are concentrated exactly there in view of a difficult emigration from mostly clayey sediments. It means that the oil source rocks are also oil-containing reserveoirs. The hydrocarbon saturation degree of the sediments is defined by the initial generative potential value and by the degree of its realization, i.e., by the values of pyrolitic parameter $\mathrm{S}_{1}$, which describes the amount of free hydrocarbons in the source sequence at the current stage of catagenic maturity. Thus, it is fair to assume that the initial total hydrocarbon geologic resources are equal to the total realized generative potential.

The results of quantitative evaluation of the generative hydrocarbon potential in the Khadum and Batalpashin sediments are as follows: the total initial generative hydrocarbon potential of the Khadum and 
Batalpashin sediments is $133.4 \mathrm{BT}$ including the Khadum Formation, 92.7 BT and the Batalpashin Formation, 40.7 BT.

The conducted evaluation showed that the initial total geologic hydrocarbon resources of the Khadum and Batalpashin oil and gas source rocks within the study region are $22.8 \mathrm{BT}$, including the Khadum Formation, 18.4 BT and Batalpashin Formation, 4.4 BT.

\section{CONCLUSIONS}

The organic matter in the Khadum and Batalpashin sediments overall in the territory of the Central and Eastern Fore-Caucasus matured to the grade of proto- and mesocatagenesis. A significant part of the Khadum and Batalpashin sediments in the study region is on the approach or within the "oil window». In the most subsided parts of the Tersk-Caspian foredeep the Khadum sediments are possibly already entering the lower zone of condensate and gas generation.

The conducted studies indicate high oil and gas generating source properties of the Khadum sediments in the Central and Eastern ForeCaucasus. They also suggest a high evaluation of discovering both conventional and unconventional hydrocarbon resources:

Conventional hydrocarbon accumulations are forecast in the development areas of conventional reservoirs and anticlinal traps in the northern areas of the Eastern Fore-Caucasus (north slope of the Kuma swell and the East Manych Trough), and also in the central and southeastern parts of the TerskCaspian Trough (Tersk-Sunzha zone, Southern Dagestan);

Perspectives of discovering unconventional hydrocarbon resources are associated with the development areas of immature «rich» and «very rich» potential oil source shaly low-permeability rocks at the initial stage of the «oil window» or at the approach to it in the source beds containing rich but relatively immature organic matter. At that, the major criterion for the exploration for shale hydrocarbons are not traps where hydrocarbons accumulate and accumulations form but directly the rock volumes where hydrocarbons were generated but did not emigrate from them. The recoverable hydrocarbons will be contained in a bed at concentration, which emerged as a result of their generation in situ. Targets of the forecast and exploration should be oil and gas plays.

For the first time in the study region was conducted quantitative evaluation of the hydrocarbon generative potential for the Maikop Formation. That enabled an evaluation of the initial total inplace hydrocarbon resources within the study region. The resources are $22.8 \mathrm{BT}$ including in the Khadum Formation, 18.4 BT and in the Batalpashin Formation, 4.4 BT.

\section{REFERENCES}

1. Morariu, D.; Aver'yanova, O.Yu. Neftegazovayageologiya. Teoriya i praktika, 2013, 8(1), 22.

2. Kerimov,V.Yu.;Mustaev, R.N.;Dmitrievsky, S.S.;Zaitsev, V.A. NeftyanoeKhozyaystvo, 2015, 9, 18-21.

3. Kerimov,V.Yu.;Mustaev, R.N.;Dmitrievsky, S.S.; Yandarbiev, N.Sh.; Kozlova, E.V. NeftyanoeKhozyaystvo, 2015, 10, 50-53.

4. Kerimov, V.Yu.; Sh i Iov, G . Ya.;Mustaev, R.N.;Dmitrievskiy, S.S. NeftyanoeKhozyaystvo, 2016, 2, 8-11.

5. Kerimov,V.Yu.;Mustaev, R.N.;Senin,
B.V.;Lavrenova, E.A. NeftyanoeKhozyaystvo, 2015, 4, 26-29.

6. Bazhenov, O. K.; Fadeev, N.P. GEOS, 2005 , 54-58.

7. Guliev, I.S.; KerimovV.Yu.; Mustaev, R.N.Doklady Earth Sciences, 2016, 471, 1, 1109-1112.

8. Espitali, J.; Durand, B.;Roussel,J. C.; Souron,C. Rev. Inst. Fr. Pétr., 1973, 28, 1, 37-66

9. Kerimov,V.Yu.;Mustaev, R.N.;Serikova, U.S.;Lavrenova, E.A.;Kruglyakova, M.V. NeftyanoeKhozyaystvo, 2015, 3, 56-60. 
10. Kerimov,V.Yu.;Lavrenova, E.A.;Mustaev, R.N.;Serikova, U.S. NeftyanoeKhozyaystvo, 2015, 1, 5-17.

11. Kerimov, V.Yu;Rachinsky, M.Z. Doklady Earth Sciences, 2016, 471, 1, 1123-1125.

12. Kerimov, V.Y.;Osipov, A.V., Mustaev, R.N.;Monakova, A.S. 16th Science and Applied Research Conference on Oil and Gas Geological Exploration and Development, GEOMODEL,2014.

13. Prishchepa, O.M.; Aver'yanova,O. Yu.;I'inskij,A.A.;Morariu,D. FGUP "VNIGRI",
2014.

14. Pelet, R. Rev. d'InstitutFrancais du Pétrole, 1985, 40, 5, 551-556.

15. Peters,K.E..AAPG Bulletin, 1986, 70, 3, 318.

16. Neruchev, S.G. M.: Nedra, 1969, 240.

17. Neruchev, S.G.; Vassoevich, N.B.; Lopatin, N.V. Dokl. sov. geol. Goryuchie iskopaemye, 1976, 47-62.

18. Kerimov,V.Yu.; Mustaev,R.N.; Bondarev, A.V. Oriental Journal of Chemistry,2016, 32, 6, 3235-3241. 